\title{
Morphology Reason Not Done
}

National Cancer Institute

\section{Source}

National Cancer Institute. Morphology Reason Not Done. NCI Thesaurus. Code

C117617.

The rationale why a morphology test was not performed. 